\author{
(). Ю. Ю. Гончарук-Хомин ${ }^{1}$, М. М. Бойчук ${ }^{1}$, С. І. Крічфалушій ${ }^{1}$, В. І. Войтович ${ }^{1}$, \\ О. Б. Кінаш ${ }^{2}$, І. А. Михайлюк ${ }^{3}$, В. М. Михайлюк ${ }^{3}$ \\ ДВНЗ «Ужгородський національний університет» ${ }^{1}$ \\ Івано-Франківський національний медичний університет ${ }^{2}$ \\ Тернопільський національний медичний університет імені I. Я. Горбачевського МОЗ України ${ }^{3}$ \\ e-mail: myroslav.goncharuk-khomyn@uzhnu.edu.ua
}

\title{
Значення параметра та особливості структури біоширини навколо дентальних імплантатів: ретроспективний аналіз даних
}

\section{ІНФОРМАЦІЯ}

Надійшла до редакції/Received: 02.10.2020 p.

Ключові слова: біологічна ширина; дентальні імплантати; ретроспективний аналіз.

\section{АНОТАЦІЯ}

Резюме. Доказово доведено, що для формування надійного м'якотканинного бар'єра в периімплантатній ділянці необхідно забезпечити умови для біологічної організації мінімальних геометричних параметрів біоширини. Дефіцит останніх асоційований із ризиком розвитку патологічних резорбтивних процесів із редукцією рівня навколишнього кісткового гребня, та низкою поступових ускладнень.

Мета дослідження - проаналізувати значення та особливості структури біологічної ширини навколо дентальних імплантатів на основі доступних даних наукової літератури.

Матеріали і методи. Формування первинної вибірки наукових публікацій, що стосувалися теми дослідження, проводилося з використанням пошукової системи Google Scholar (https://scholar. google.com/) та бази даних PubMed (https://pubmed.ncbi.nlm.nih.gov/) із застосуванням відповідних ключових слів («biowidth», «biological width», «dental implants») та Mesh-термінів (алгоритм пошуку: («biology»[MeSH Terms] OR «biology»[All Fields] OR «biological»[All Fields]) AND width[All Fields] AND («dental implants»[MeSH Terms] OR («dental»[All Fields] AND «implants»[All Fields]) OR «dental implants»[All Fields])).

Результати досліджень та їх обговорення. В результаті проведеного аналізу вдалось виокремити такі основні характеристики зони комплексу біологічної ширини навколо дентальних імплантатів: апікальну частину епітеліальної складової, що характеризується мінімальною товщиною з формуванням навколо поверхні імплантату тонких гемідесмосомних структур; сполучнотканинну складову, яка характеризується наявністю безпосереднього контакту з поверхнею імплантату без ознак вираженого функціонального прикріплення; зону безпосереднього контакту, що характеризується відсутністю кровоносних судин та великою кількістю клітин фібробластів у структурі між колагеновими волокнами; латеральніше вищезгаданої зони відмічається зменшення кількості фібробластів та паралельне зростання величини колагенових волокон і кількісного складу судинних структур.

Висновки. Більшість досліджень, асоційованих із вивченням різних аспектів формування комплексу біологічної ширини навколо дентальних імплантатів, проводилася на тваринних моделях, що певною мірою обмежує можливості для безпосередньої інтерпретації отриманих результатів у клінічній стоматологічній практиці. Дані, отримані в ході як лабораторних, так і клінічних досліджень, свідчать про те, що вихідний дефіцит товщини м'яких тканин у периімплантатній ділянці пов'язаний із процесом редукції рівня кісткового гребеня задля забезпечення формування необхідних параметрів біоширини. 
Вступ. Термін «біологічна ширина» вперше сформулювали у 1961 p. Gargiulo et al. (1961) [1], хоча попередньо комплекс сполучнотканинного прикріплення та сполучного епітелію описали у роботах B. Gottlieb (1921) [2], Marfino et al. (1959) [3], Sicher та інші (1959) [4, 5]. 3а даними Glauser et al. (2005), геометрична величина комплексу біологічної ширини складає 4-4,5 мм та включає: товщину боріздкової складової - 0,2-0,5 мм, товщину сполучного епітелію - 1,4-1,9 мм, товщину сполучної тканини - 0,7-2,6 мм [6]. При цьому в дослідженні Kan (2003) висота комплексу біологічного прикріплення навколо дентальних імплантатів сягала 6,17 мм із мезіального боку, 5,93 мм - із дистального боку та 3,63 мм - з вестибулярного боку. В середньому параметр біологічної ширини навколо дентальних імплантатів на 1,5 мм перевищує аналогічний показник навколо власних зубів [7].

Доказово доведено, що для формування надійного м'якотканинного бар'єра в периімплантатній діяльності необхідно забезпечити умови для біологічної організації мінімальних геометричних параметрів біоширини [8-10]. Дефіцит останніх асоційований із ризиком розвитку патологічних резорбтивних процесів з редукцією рівня оточуючого кісткового гребня, та низкою послідуючих ускладнень [10-12].

Метою дослідження було проаналізувати значення та особливості структури біологічної ширини навколо дентальних імплантатів на основі доступних даних наукової літератури.

Матеріали і методи. Формування первинної вибірки наукових публікацій, що стосувалися теми дослідження проводилося 3 використанням пошукової системи Google
Scholar (https://scholar.google.com/) та бази даних PubMed (https://pubmed.ncbi.nlm.nih. gov/) із застосуванням відповідних ключових слів («biowidth», «biological width», «dental implants») та Mesh-термінів (алгоритм пошуку: («biology»[MeSH Terms] OR «biology»[All Fields] OR «biological»[All Fields]) AND width[All Fields] AND («dental implants»[MeSH Terms] OR («dental»[All Fields] AND «implants»[All Fields]) OR «dental implants»[All Fields])) [13, 14].

Відбір цільової вибірки публікацій передбачав первинний аналіз назв та анотацій усіх знайдених статей із подальшим виключенням із кількості таких дублікатів, знайдених у базі даних PubMed та за допомогою пошукової системи Google Scholar, статей, що безпосередньо не стосувалися поставленої мети дослідження та таких, в яких було висвітлено уже попередньо відібрані для аналізу дані.

Параметри гістологічних особливостей структур-компонентів біологічної ширини, механізмів формування та особливостей впливу різних імплантатасоційованих факторів на організацію біологічної ширини використовувались в якості категорій контентаналізу.

Систематизацію та групування даних проводили із застосування прикладного програмного забезпечення Microsoft Excel 2019 (Microsoft Office, 2019) та з використанням принципу розподілу результатів опрацювання текстових масивів даних згідно з попередньо сформульованими категоріями контент-аналізу.

Результати досліджень та їх обговорення. Усього у базі даних PubMed з використанням відповідних Mesh-термінів було ідентифіковано 269 публікацій, розподіл котрих по роках представлений на рисунку 1.

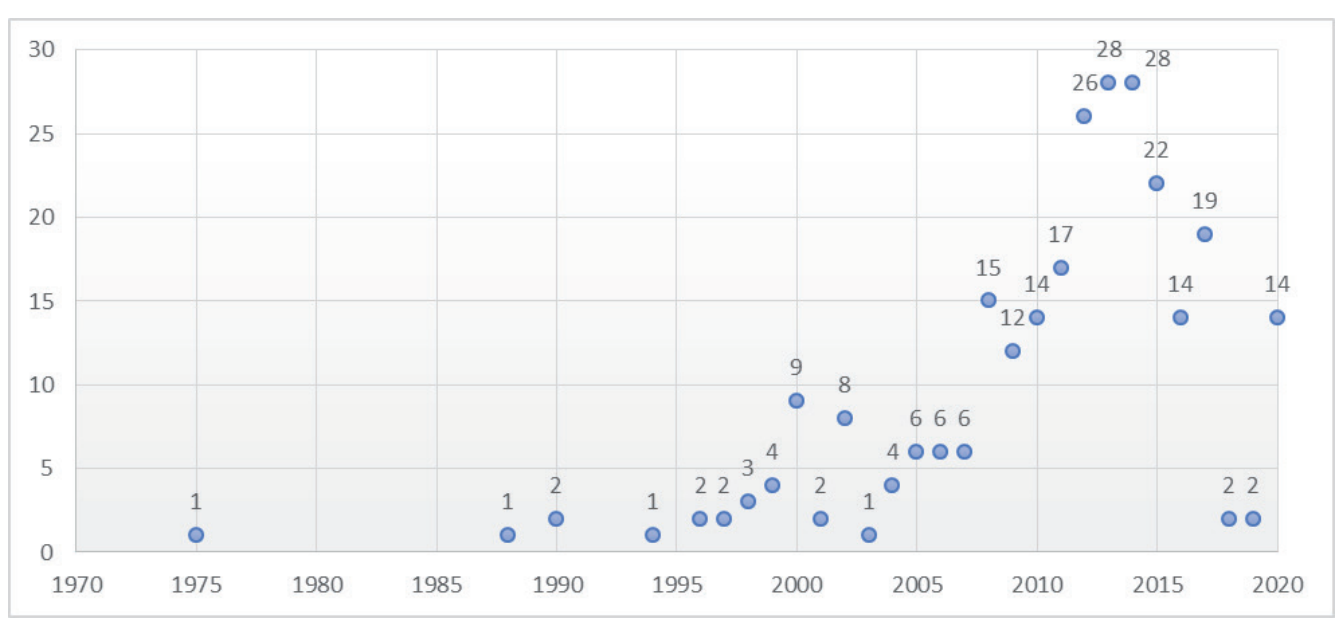

Puc. 1. Розподіл кількості публікацій, ідентифікованих у базі даних PubMed, із використанням відповідного Mesh-алгоритму пошуку. 
Пошукова система Google Scholar дозволила ідентифікувати 867 публікацій, що первинно відповідали критеріям пошуку за ключовими словами.
Алгоритм пошуку та відбору публікацій у базі даних PubMed та з використанням пошукової системи Google Scholar представлений на рисунку 2.

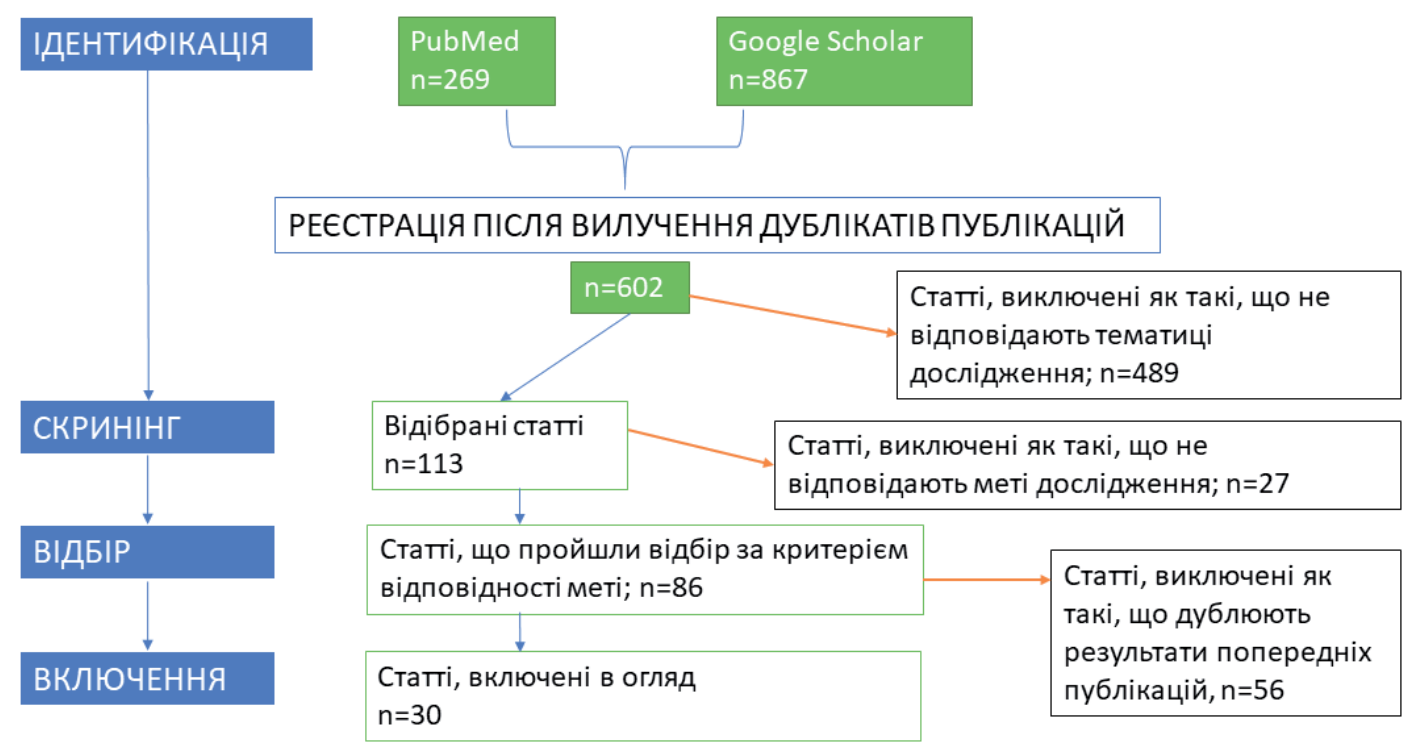

Puc. 2. Алгоритм пошуку та відбору публікацій.

За даними Listgarten et al. (1991), комплекс біологічної ширини навколо дентальних імплантатів можна стратифікувати на три наступні зони: боріздковий епітелій, сполучний епітелій та сполучна тканин [15].

У класичному дослідженні J. S. Hermann та D. Buser (2000) відмітили статистично значимі зміни величин глибини периімплантатної боріздки (ГПБ), сполучного епітелію (СЕ) та сполучнотканинної складової (СС) через $3 ; 6$ та 15 місяців після проведення імплантації: ГПБ - 0,49 мм, 0,50 мм та 0,16 мм відповідно; CE - 1,16 мм, 1,44 мм та 1,88 мм відповідно; та СС - 1,36 мм, 1,01 мм та 1,05 мм відповідно [16]. Проте середня величина суми даних показників у період контрольної оцінки через 3; 6 та 15 місяців залишалась сталою, що дозволило авторам констатувати стабільність біологічної ширини як сформованого комплексу тканин периімплантатної ділянки [16]. Протягом періоду моніторингу автори відмітили зменшення параметрів глибини боріздки та сполучнотканинної складової, при цьому патерн редукції сполучнотканинної складової характеризувався більш раннім початком [16]. Компенсація зменшення даних параметрів у структурі збереження відносно сталої величини біологічної ширини пов'язана із зростання параметру сполучного епітелію. Поряд з тим вищеописані варіації даних складових у різ- ні терміни спостереження дозволяють припустити потенційну наявність відповідного впливу на формування таких оперативно-, конструкційно- чи протетичноасоційованих факторів, та чинників, пов'язаних із вихідним станом тканин у ділянці проведення процедури імплантації.

Незважаючи на доведену морфологічну аналогічність, сполучний епітелій навколо дентальних імплантатів є похідним від епітелію ротової порожнини та характеризується вираженим стоншенням в апікальному напрямку (складаючись лише із базального та зернистого шарів), разом з тим, як сполучний епітелій комплексу біологічної ширини власних зубів є похідним редукованого емалевого епітелію [5, 9, 10, 12, 16, 17]. Проліферація епітеліальної складової біоширини навколо встановлених дентальних імплантатів відмічається уже через 10-14 днів після проведення оперативного втручання (за даними, отриманими в ході аналізу тваринних досліджуваних моделей), з формуванням цілісного епітеліального бар'єра через 6-8 місяців [12, 16-20]. Гістологічні дослідження дозволили встановити факт можливої міграції клітин, асоційованих із розвитком запалення, через структуру сполучного епітелію в якості біологічної відповіді на наявність патологічної бактеріальної контамінації з боку ротової порож- 
нини [5, 9, 10, 12, 17, 18]. Відтак епітеліальну складову комплексу біологічної ширини можна розцінювати як один із механізмів захисту та попередження бактеріальної інвазії.

Крім того, захисна функція сполучного епітелію у структурі пародонтального комплексу забезпечується за рахунок наступних механізмів: 1) ендоцитоз та клітинний захист за рахунок нейтрофілів; 2) самоочищення та антибактеріальні властивості ясенної рідини; 3) десквамація клітинного шару епітелію; 4) нівелювання безпосередньої дії зовнішніх факторів [21]. Незважаючи на аналогічність структури сполучного епітелію навколо дентальних імплантатів, слабша функціональна герметична здатність такого потенційно може бути пов'язана із електростатичними характеристиками внутрішньокісткової титанової опори [21].

За даними гістометричних досліджень щільніший зв'язок в ділянці інтерфейсу з'єднання зуба $з$ навколишніми м'якими тканинами обгрунтований за рахунок наступних зв'язків сполучного епітелію: 1) між світлою пластинкою базальної мембрани та клітинами сполучного епітелію, який укріплений гемідесмосомними з'єднаннями та епітеліальною адгезією на рівні емалі; 2) між щільною пластинкою базальної мембрани та емаллю; 3) між базальною пластинкою сполучного епітелію та сполучною тканиною [18, 21]. Наявність структур внутрішньої частини базальної пластинки та гемідесмосом була відмічена лише в апікальній частині інтерфейсу «сполучний епітелій-імплантат» на відміну від таких у ділянці зубів, де вони спостерігалися упродовж усього інтерфейсу [5, 9, 17, 18, 21]. Відсутність вищеописаних зв'язків, характерна для комплексу біологічної ширини в ділянці встановлених внутрішньокісткових опор, може бути асоційована із слабшим характером зв'язку між сполучним епітелієм та поверхнею імплантату, хоча доказових даних, які могли підтвердити дану гіпотезу, досі не отримано, окрім таких, що стосуються ідентифікації адгезивних білків. у більшості попередньо проведених досліджень характер з'єднання сполучного епітелію до поверхні імплантату формується завдяки базальній пластинці та гемідесмосом [5, 9, 17, 18, 21].

У класичній роботі Berglundh et al. (1996) було відмічено, що сполучнотканинна складова комплексу біологічної ширини навколо дентальних імплантатів відрізняється перева- жаючою кількістю колагенових волокон, відносно зниженою кількістю клітин фібробластів та судинних структур порівняно 3 комплексом біологічної ширини навколо власних зубів [10]. Відповідна ширини сполучнотканинної складової також асоційована із попередженням прогресуючої апікальної міграції епітелію [10]. Повторне переформування біологічної ширини з прогресуючою апікальною міграцією епітелію може бути однією 3 причин втрати вихідного рівня кісткового гребеня в периімплантатній ділянці після повторних випадків приєднання/від'єднання супраструктур від встановленої конструкції внутрішньокісткового імплантату [5, 9, 10]. Розмірна стабільність сполучнотканинної складової у структурі комплексу біологічної ширини навколо дентальних імплантатів $€$ вищою за розмірну стабільність епітеліальної складової $[5,9,10]$.

Патерни організації колагенових волокон у структурі комплексу біологічної ширини, окрім загальновираженої ознаки паралельного ходу таких відносно поверхні імплантату, характеризуються вираженою варіативністю та різнонаправленістю [16, 17, 22]. У низці попередньо проведених гістологічних досліджень із використанням різних досліджуваних тваринних моделей було встановлено факт наявності функціональної орієнтації пучків колагенових волокон навколо дентальних імплантатів [16, 17, 22]. В зоні безпосереднього контакту сполучної тканини, як складової комплексу біологічної ширини, було відмічено наявність аваскулярних волокон циркулярної направленості, щільність організації котрих зменшувалась у міру віддаленості від поверхні внутрішньокісткової титанової дентальної опори [16, 17, 22]. Попередні автори також відмітили наявність значної кількості колагену 5 типу з резистентністю до колагенази навколо встановлених титанових опор, що дозволило припустити, що сполучнотканинна складова комплексу біологічної ширини навколо дентальних імплантатів характеризується наявністю ознак перебігу хронічного запалення [21].

У гістологічних дослідженнях K. Makigusa (2009) було уточнено, що в ділянці власних зубів кровозабезпечення навколишніх м'яких тканин реалізується за рахунок трьох основних джерел: 3 ділянки пародонтальної зв'язки до ділянки сполучнотканинної складової, $з$ ділянки альвеолярного гребеня до ділян- 
ки пародонтальної зв'язки та безпосередньо 3 ділянки альвеолярного гребеня до ділянки сполучнотканинної складової [18]. На відміну від механізму кровозабезпечення комплексу біологічної ширини власних зубів, що реалізується за рахунок супраперіостальних судин та судинного сплетення пародонтальної зв'язки, навколо імплантатів даний механізм забезпечується лише за рахунок супраперіостальних судин $[9,16,18]$. Дані скануючої електронної мікроскопії підтвердили також наявність капілярних петель у структурі сполучної тканини під зонами боріздкового та сполучного епітелію, що аналогічні таким у структурі пародонта власних зубів [23]. Berglundh та Lindhe (1990) також відмітили, що в зоні переходу сполучного епітелію в сполучну тканину наявність достатньої кількості кровоносних судин виражено меншого діаметра [10]. Відповідно вища чутливість периімплантатних м'яких тканин до ятрогенних маніпуляцій частково може бути пов'язана з відсутністю структури пародонтальної зв'язки як одного 3 джерел кровозабезпечення.

Крім превалюючої кількості фібробластів відносно кількості судинних структур у дослідженнях Moon et al. (1990) також було зазначено специфічний патерн орієнтації клітин, довга вісь котрих позиціонувалася переважно паралельно до поверхні імплантату [24].

Резюмуючи попередньо доступні дані T. Lincevikus та P. Apse (2018), у свою чергу, виокремлювали такі основні характеристики зони комплексу біологічної ширини навколо дентальних імплантатів: апікальну частину епітеліальної складової, що характеризується мінімальною товщиною $з$ формуванням навколо поверхні імплантату тонких гемідесмосомних структур; сполучнотканинну складову, що характеризується наявністю безпосереднього контакту з поверхнею імплантату без ознак вираженого функціонального прикріплення; зону даного контакту, яка характеризується відсутністю кровоносних судин та великою кількістю клітин фібробластів у структурі між колагеновими волокнами; латеральніше даної зони відмічається зменшення кількості фібробластів та паралельне зростання величини колагенових волокон та кількісного складу судинних структур [9].

Морфологічних відмінностей у структурі комплексу біологічної ширини навколо дентальних імплантатів із різним рівнем шорохуватості поверхні виявити не вдалось, проте відмічалась специфіка суборієнтації волокон [5, 25]. Так, у ділянці шорохуватих поверхонь імплантатів відмічалось структурування перпендикулярних волокон, разом з тим, як в ділянці гладеньких поверхонь зберігався паралельний хід волокон $[5,25]$. У ділянці імплантатів з окисноопрацьованою або ж кислотнопротравленою поверхнею відмічався менш виражений патерн апікальної міграції епітелію та довший тип сполучнотканинного з'єднання [9]. При цьому автори висловили припущення, що такі відмінності можуть бути пов'язані не так із мікротопографією поверхні імплантатів, як із рівнем їх гідрофільності [9].

За даними проведених гістологічних досліджень, вплив протоколу проведення імплантації чи часу навантаження встановлених внутрішньокісткових опор на принципову структуру біологічної ширини не $є$ домінантнозначимим [9, 26, 27]. Результати встановлення залежності між величиною сформованого комплексу біологічної ширини та фактом проведення негайної імплантації після екстракції свідчать про можливість формування більш виражених показників біологічної ширини порівняно з відстроченим протоколом встановлення внутіршньокісткових опор за рахунок зростання геометричних параметрів саме сполучнотканинної складової. Аналітичне дослідження A. Sculean (2014) дозволило сформулювати гіпотезу, що вищі геометричні показники комплексу біологічної ширини навколо негайно встановлених імплантатів асоційовані з швидкою апікальною міграцією сполучного епітелію периімплантатної ділянки [28].

Дані, що вказують на формування вищих параметрів біологічної ширини залежно від глибини встановлення дентальних імплантатів є доказово-обмеженими і носять гіпотетичний, а не заключний характер, відтак потребують подальшої уточнення та перевірки. У літературному огляді Т. Lincevikus та P. Apse (2018), автори, проводячи диференційований аналіз доступних даних з урахуванням рівня ïх доказової значимості, підтвердили, що положення мікрощілини в ділянці інтерфейсу з'єднання імплантату та абатмента впливає на вертикальний параметр величини комплексу біологічної ширини [9]. На думку B. Negri et al. (2015), субкрестальне встановлення дентального імплантату зменшує відстань від плеча імплантату до першого контакту з кістковою тканини, і таким чином, дозволяє сформува- 
ти біологічну ширини в найбільш корональному положенні, однак навіть такий підхід не можна розцінювати як достатньо ефективний 3 точки зору мінімізації рівня втрати навколишньої кісткової тканини, оскільки отримані параметри біоширини навколо імплантатів встановлених на рівні гребеня та субкрестально статистично не відрізнялися [27].

Незважаючи на те, що абсолютні показники складових сполучного епітелію та сполучнотканинного шару в умовах сепарації клаптя були вищими, статистичної різниці таких при порівнянні даних після проведення безклаптевих та клаптевих втручань зареєструвати не вдалось. У дослідженні J. Blanco (2010) було відмічено, що з точки зору вертикальної складової біологічна ширина з вестибулярної сторони дентальних імплантатів, встановлених без сепарації клаптя, була меншою, аніж у випадках імплантації із сепарацією клаптя [26]. Проте такий результат дослідники пов'язують не тільки із впливом специфіки виконання ятрогенного втручання, але й 3 впливом вихідного біотипу тканин у досліджуваній ділянці. При цьому вчені також відмітили, що величина епітеліальної складової комплексу досліджуваної біоширини у двох порівнюваних групах не відрізнялась, разом з тим, як відповідні показники різниці стосувалися саме сполучнотканинної складової [26]. У дослідженнях Berglundh et al. (1991, 1996, 1999), хірургічне стоншення структури клаптя навколо дентального імплантату було асоційоване із редукцією рівня резидуального гребеня з відновленням вихідних параметрів біологічної ширини [10, 24, 29].

Відмінності у співвідношенні складових біологічної ширини були зареєстровані у дослідженні Romanos et al.: товщина сполучнотканинної складової на верхній щелепі статистично перевищувала аналогічні показники на нижній, зберігаючи при цьому відносно аналогічну товщину складової сполучного епітелію [20].

У дослідженні R. Judgar et al. (2014) було відмічено, що навколо двокомпонентних дентальних імплантатів відмічається формування більшого з точки зору вертикального параметру комплексу біологічної ширини за рахунок сполучнотканинної складової [30]. При цьому показники глибини боріздки та розміру сполучного епітелію були аналогічними в ділянці одно- та двокомпонентних конструкцій імплантатів [30]. Дані, отримані в кластерному рандомізованому дослідженні S. Spinato et al. (2019), дозволили авторам припустити, що процес формування біологічної ширини навколо дентальних імплантатів залежить і від висоти використовуваного абатмента, незалежно від вихідної товщини слизової [31]. Аналогічні результати були описані й у попередньо проведеному дослідженні S. Vervaeke et al. (2014) [32].

В умовах лабораторного моделювання периімплантиту було встановлено, що механічне порушення цілості сполучного епітелію казуїстично пов'язано із подальшою резорбцією кісткової тканини в периімплантатній ділянці; при цьому початок запальних змін м'яких танин, асоційований із акумуляцією бактеріального нальоту в умовах збереження цілості складових комплексу біологічної ширини, не характеризувався прогресуючою редукцією рівня кісткового гребеня у периімплантатній ділянці $[9,19]$.

Більшість досліджень, асоційована із вивченням різних аспектів формування комплексу біологічної ширини навколо дентальних імплантатів, проводилися на тваринних моделях, що певною мірою обмежує можливості для безпосередньої інтерпретації отриманих результатів у клінічній стоматологічній практиці. 3 іншого боку, в літературному огляді 3 урахуванням значимості рівня доказовості проаналізованих даних, T. Lincevikus та P. Apse (2018) відмітили, що не усі аспекти комплексу біологічної ширини, як предмета наукового та клінічного інтересу, можуть бути досліджені безпосередньо серед стоматологічних пацієнтів з урахуванням відповідних етичних обмежень [9]. При цьому однак було погоджено, що відносно конкретно до параметру біологічної ширини дослідження на тваринах характеризуються вищим рівнем клінічної значимості, аніж аналогічні дослідження на лабораторносформованих моделях.

Висновки. В результаті проведеного ретроспективного огляду літературних даних вдалось висвітлити специфічні аспекти організації комплексу біологічної ширини навколо дентальних імплантатів з урахуванням особливостей трьох основних зон: боріздкового епітелію, сполучного епітелію та сполучної тканини. Крім того, було розглянуто потенційний вплив на процес формування та параметри біоширини таких факторів, як глибина встановлення імплантату, особливості конструкції внутрішньокісткової опори, особли- 
вості мікротопографії її поверхні, часу проведення імплантації та специфіки хірургічного протоколу маніпуляції. Дані, отримані в ході як лабораторних, так і клінічних досліджень, свідчать про те, що вихідний дефіцит товщи- ни м'яких тканин в периімплантатній ділянці пов'язаний із процесом редукції рівня кісткового гребеня задля забезпечення формування необхідних параметрів біоширини.

\section{(). Ю. Гончарук-Хомин ${ }^{1}$, М. М. Бойчук ${ }^{1}$, С. И. Кричфалуший ${ }^{1}$, В. И. Войтович ${ }^{1}$, О. Б. Кинаш ${ }^{2}$, И. А. Мыхайлюк ${ }^{3}$, В. Н. Мыхайлюк ${ }^{3}$}

ГВУЗ «Ужгородский национальный университет» ${ }^{1}$

Ивано-Франковский национальный медицинский университет ${ }^{2}$

Тернопольский национальный медицинский университет имени И. Я. Горбачевского МО3 Украины ${ }^{3}$

\section{Значение параметра и особенности структуры биоширины вокруг дентальных имплантатов: ретроспективный анализ данных}

Резюме. Доказательно установлено, что для формирования надежного мягкотканного барьера в периимплантатной области необходимо обеспечить условия для биологической организации минимальных геометрических параметров биоширины. Дефицит последних ассоциирован с риском развития патологических резорбтивных процессов с редукцией уровня окружающего костного гребня, и рядом последующих осложнений.

Цель исследования - проанализировать значение и особенности структуры биологической ширины вокруг дентальных имплантатов на основе доступных данных научной литературы.

Материалы и методы. Формирование первичной выборки научных публикаций, касающихся темы исследования, проводилось с использованием поисковой системы Google Scholar (https://scholar. google.com/) и базы данных PubMed (https://pubmed.ncbi.nlm.nih.gov/) с применением соответствующих ключевых слов («biowidth», «biological width», «dental implants») та Mesh-термінів (алгоритм пошуку: («biology»[MeSH Terms] OR «biology»[All Fields] OR «biological»[All Fields]) AND width[All Fields] AND («dental implants»[MeSH Terms] OR («dental»[All Fields] AND «implants»[All Fields]) OR «dental implants»[All Fields])).

Результаты исследований и их обсуждение. В результате проведенного анализа удалось выделить следующие основные характеристики зоны комплекса биологической ширины вокруг дентальных имплантатов: апикальную часть эпителиальной составляющей, которая характеризуется минимальной толщиной с формированием вокруг поверхности имплантата тонких гемидесмосомальных структур; соединительнотканевую составляющую, которая характеризуется наличием непосредственного контакта с поверхностью имплантата без признаков выраженного функционального прикрепления; зону непосредственного контакта, что характеризуется отсутствием кровеносных сосудов и большим количеством клеток фибробластов в структуре между коллагеновыми волокнами; латеральнее вышеупомянутой зоны отмечается уменьшение количества фибробластов и параллельный рост величины коллагеновых волокон и количественного состава сосудистых структур.

Выводы. Большинство исследований, ассоциированных с изучением различных аспектов формирования комплекса биологической ширины вокруг дентальных имплантатов, проводились на животных моделях, что в определенной степени ограничивает возможности для непосредственной интерпретации полученных результатов в клинической стоматологической практике. Данные, полученные в ходе как лабораторных, так и клинических исследований, свидетельствуют о том, что исходный дефицит толщины мягких тканей в периимплантатной области связан с процессом редукции уровня костного гребня для обеспечения формирования необходимых параметров биоширины.

Ключевые слова: биологическая ширина; дентальные имплантаты; ретроспективный анализ. 


\title{
(CM. Yu. Goncharuk-Khomyn ${ }^{1}$, M. M. Boychuk ${ }^{1}$, S. I. Krichfalushij ${ }^{1}$, V. I. Voytovich ${ }^{1}$, O. B. Kinash², I. A. Mykhailiuk ${ }^{3}$, V. M. Mykhailiuk ${ }^{3}$
}

Uzhhorod National University ${ }^{1}$

Ivano-Frankivsk National Medical University ${ }^{2}$

I. Horbachevsky Ternopil National Medical University ${ }^{3}$

\section{The value of the biological width parameter and its structure around the dental implants: a retrospective analysis of the data}

\begin{abstract}
Summary. It has been proven that in order to form a reliable soft tissue barrier at the peri-implant area, it is necessary to provide conditions for the biological organization of the minimum geometric parameters of the biological width. Deficiency of the latter is associated with the risk of pathological resorptive processes, further reduction of the surrounding bone ridge level, and a number of subsequent complications.

The aim of the study - to analyze the significance of biological width and its structure features around dental implants on the basis of available scientific literature data.

Materials and Methods. The initial sample of scientific publications related to the research topic was formed using the Google Scholar search engine (https://scholar.google.com/) and the PubMed database (https:// pubmed.ncbi.nlm.nih.gov/) considering relevant keywords ("biowidth”, "biological width”, “dental implants") and Mesh-terms (search algorithm: ("biology"[MeSH Terms] OR "biology"[All Fields] OR "biological"[All Fields]) AND width[All Fields] AND ("dental implants"[MeSH Terms] OR ("dental"[All Fields] AND "implants"[All Fields]) OR "dental implants"[All Fields])).

Results and Discussion. As a result of the provided analysis it was possible to highlight the following main characteristics of the biological width complex around dental implants: the apical part of the epithelial component characterized by minimal thickness with the formation of thin hemidesmosomal structures around the implant surface; the connective tissue component characterized by the presence of direct contact with the implant surface without signs of pronounced functional attachment; the area of direct contact characterized by the absence of blood vessels and a large number of fibroblast cells in the structure between the collagen fibers; lateral to the above-mentioned zone decrease in the number of fibroblasts and a parallel increase in the size of collagen fibers and the quantitative composition of vascular structures was noted.

Conclusions. Most studies associated with the various aspects of the biological width formation around dental implants have been conducted within animal study models, which to some extent limits the possibilities for direct interpretation of the results in clinical dental practice. Data from both laboratory and clinical studies suggest that the initial deficit in soft tissue thickness at the peri-implant area associated with the process of bone ridge reduction to ensure the formation of the necessary biological width parameters.
\end{abstract}

Key words: biological width; dental implants; retrospective analysis.

\section{СПИСОК ЛІТЕРАТУРИ}

1. Gargiulo A. W. Dimensions and relations of the dentogingival junction in humans / A. W. Gargiulo, F. M. Wentz, B. Orban // J. Periodontol. - 1959. - Vol. 32 (3). - P. 261-267.

2. Gottlieb B. Der Epithelansatz am Zahne / B. Gottlieb // Deutsche Monatsschrift fur Zahnheilkunde. - 1921. Vol. 5. - P. 142-147.

3. Marfino N. R. Repair of the dento-gingival junction following surgical intervention / N. R. Marfino, B. J. Orban, F. M. Wentz // Jю Periodontol. - 1959. Vol. 30. - P. 180.

4. Sicher H. Changing concepts of the supporting dental structures / H. Sicher // Oral Surg. Oral Med. Oral Pathol. - 1959. - Vol. 12 (1). - P. 31-35.

5. Biologic width around dental implants: An updated review / Z. Rezaei Esfahrood, M. Kadkhodazadeh, P. Gholamin [et al.] // J. Dent. Materials Techniq. - 2016. - Vol. 5 (2). - P. 68-81.

6. Periimplant soft tissue barrier at experimental one piece mini implants with different surface topography in humans: a light microscopic overview and histometric analysis / R. Glauser, P. Schüpbach, J. Gottlow, C. H. Hämmerle // Clin. Implant Dent. Relat. Res. - 2005. - Vol. 7. - P. s44-s51.

7. Dimensions of peri implant mucosa: an evaluation of maxillary anterior single implants in humans / J. Y. Kan, K. Rungcharassaeng, K. Umezu, J. C. Kois // J. Periodontol. - 2003. - Vol. 74 (4). - P. 557-562.

8. Khuller N. Biologic width: Evaluation and correction of its violation / N. Khuller, N. Sharma // J. Oral Health Comm. Dent. - 2009. - Vol. 3 (1). - P. 20-25.

9. Linkevicius T. Biologic width around implants. An evidence-based / T. Linkevicius, P. Apse // Stomatologija. - 2008. - Vol. 10 (1). - P. 27-35.

10. Berglundh T. Dimension of the periimplant mucosa: biological width revisited / T. Berglundh, J. Lindhe // J. Clin. Periodontol. - 1996. - Vol. 23 (10). - P. 971-973.

11. The causes of early implant bone loss: myth or 
science? / T. J. Oh, J. Yoon, C. E. Misch, H. L. Wang // J. Periodontol. - 2002. - Vol. 73 (3). - P. 322-333.

12. Dhir S. Significance and clinical relevance of biologic width to implant dentistry / S. Dhir // J. Interdisciplinary Dent. - 2012. - Vol. 2 (2). - P. 84.

13. Walters W. H. Google Scholar search performance: Comparative recall and precision/W. H. Walters // Portal: Libraries and the Academy. - 2009. - Vol. 9 (1). - P. 5-24. 14. Richter R. R. Using MeSH (medical subject headings) to enhance PubMed search strategies for evidencebased practice in physical therapy / R. R. Richter, T. M. Austin // Phys. Ther. - 2012. - Vol. 92 (1). - P. 124132.

15. Periodontal tissues and their counterparts around endosseous implants / M. A. Listgarten, N. P. Lang, H. E. Schroeder, A. Schroeder // Clin. Oral Implants Res. - 1991. - Vol. 2 (1). - P. 1-19.

16. Biologic width around titanium implants. A physiologically formed and stable dimension over time / J. S. Hermann, D. Buser, R. K. Schenk [et al.] // Clin. Oral Implants Res. - 2000. - Vol. 11 (1). - P. 1-11.

17. Biologic width around titanium implants. A histometric analysis of the implanto gingival junction around unloaded and loaded nonsubmerged implants in the canine mandible / D. L. Cochran, J. S. Hermann, R. K. Schenk [et al.] // J. Periodontol. - 1997. - Vol. 68 (2). - P. 186-197.

18. Makigusa K. Histologic comparison of biologic width around teeth versus implant: The effect on bone preservation / K. Makigusa // J. Implant Reconstr. Dent. 2009. - Vol. 1 (1). - P. 20-24.

19. Biologic width dimensions-a systematic review / J. C. Schmidt, P. Sahrmann, R. Weiger [et al.] // J. Clin. Periodontol. - 2013. - Vol. 40 (5). - P. 493-504.

20. Biologic width and morphologic characteristics of soft tissues around immediately loaded implants: studies performed on human autopsy specimens / G. E. Romanos, T. Traini, C. B. Johansson, A. Piattelli // J. Periodontol. - 2010. - Vol. 81 (1). - P. 70-78.

21. Soft tissue sealing around dental implants based on histological interpretation / I. Atsuta, Y. Ayukawa, R. Kondo [et al.] // J. Prosthodont. Res. - 2016. - Vol. 60 (1). - P. 3-11.

22. Biologic Width around one and two piece titanium implants: A histometric evaluation of unloaded nonsubmerged and submerged implants in the canine mandible / J. S. Hermann, D. L. Cochran, J. S. Hermann [et al.] // Clin. Oral Implants Res. - 2001. - Vol. 12 (6). P. 559-571.

23. Selliseth N. J. Microvascular adaptation to transmucosal implants. A scanning electron microscopic study in the rat / N. J. Selliseth, K. A. Selvig // Clin. Oral Implants Res. - 1995. - Vol. 6 (4). - P. 205-212.

24. The barrier between the keratinized mucosa and the dental implant: an experimental study in the dog / I. S. Moon, T. Berglundh, I. Abrahamsson [et al.] // J. Clin. Periodontol. - 1999. - Vol. 26 (10). - P. 658-663.

25. Biologic width adjacent to loaded implants with machined and rough collars in the do / D. L. Cochran, M. Obrecht, K. Weber [et al.] // Int. J. Periodont. Restorative Dent. - 2014. - Vol. 34 (6). - P. 773-779.

26. Biological width following immediate implant placement in the dog: flap vs. flapless surgery / J. Blanco, C.C. Alves, V. Nuñez [et al.] // Clin. Oral Implants Res. 2010. - Vol. 21 (6). - P. 624-631.

27. Biological width formation to immediate implants placed at different level in relation to the crestal bone: an experimental study in dogs / B. Negri, M. Lopez Mari, J. E. Maté Sánchez de Val [et al.] // Clin. Oral Implants Res. - 2015. - Vol. 26 (7). - P. 788-798.

28. Sculean A. Soft tissue wound healing around teeth and dental implants / A. Sculean, R. Gruber, D. D. Bosshardt // J. Clin. Periodontol. - 2014. - Vol. 41. - P. S6-22.

29. The soft tissue barrier at implants and teeth / T. Berglundh, J. Lindhe, I. Ericsson [et al.] // Clin. Oral Implants Res. - 1991. - Vol. 2 (2). - P. 81-90.

30. Biological width around one-and two-piece implants retrieved from human jaws / R. Judgar, G. Giro, E. Zenobio [et al.] // BioMed Res. Int. - 2014. - Vol. 3 P. 850120 .

31. Biological width establishment around dental implants is influenced by abutment height irrespective of vertical mucosal thickness: A cluster randomized controlled trial / S. Spinato, C Stacchi, T. Lombardi [et al.] // Clin. Oral Implants Res. - 2019. - Vol. 30 (7). P. 649-659.

32. The influence of initial soft tissue thickness on peri implant bone remodeling / S. Vervaeke, M. Dierens, J. Besseler, H. De Bruyn // Clin. Implant Dent. Relat. Res. - 2014. - Vol. 16 (2). - P. 238-247.

\section{REFERENCES}

1. Gargiulo, A.W., Wentz, F.M., \& Orban, B. (1961). Dimensions and relations of the dentogingival junction in humans. J. Periodontol., 32 (3), 261-267.

2. Gottlieb, B. (1921). Der Epithelansatz am Zahne. Deutsche Monatsschrift fur Zahnheilkunde, 5, 142-147.

3. Marfino, N.R, Orban, B.J, \& Wentz, F.M. (1959). Repair of the dento-gingival junction following surgical intervention. J. Periodontol, 30, 180.

4. Sicher, H. (1959). Changing concepts of the supporting dental structures. Oral Surg. Oral Med. Oral Pathol., 12 (1), 31-35.

5. Rezaei Esfahrood, Z., Kadkhodazadeh, M., Gholamin, P., Amid, R., Passanezi, E., \& Hosein Zadeh, H. (2016).

Biologic width around dental implants: An updated review. J. Dent. Materials Techniq., 5 (2), 68-81.

6. Glauser, R., Schüpbach, P., Gottlow, J., \& Hämmerle, C.H. (2005). Periimplant soft tissue barrier at experimental one piece mini implants with different surface topography in humans: a light microscopic overview and histometric analysis. Clin. Implant Dent. Relat. Res., 7, s44-s51.

7. Kan, J.Y., Rungcharassaeng, K., Umezu, K., \& Kois, J.C. (2003). Dimensions of per implant mucosa: an evaluation of maxillary anterior single implants in humans. $J$. Periodontol., 74 (4), 557-562.

8. Khuller, N., \& Sharma, N. (2009). Biologic width: 
Evaluation and correction of its violation. J. Oral Health Comm. Dent., 3 (1), 20-25.

9. Linkevicius, T., \& Apse, P. (2008). Biologic width around implants. An evidence-based. Stomatologija, 10 (1), 27-35.

10. Berglundh, T., \& Lindhe, J. (1996). Dimension of the periimplant mucosa: biological width revisited. J. Clin. Periodontol., 23 (10), 971-973.

11. Oh, T.J., Yoon, J., Misch, C.E., \& Wang, H.L. (2002). The causes of early implant bone loss: myth or science? J. Periodontol., 73 (3), 322-333.

12. Dhir, S. (2012). Significance and clinical relevance of biologic width to implant dentistry. J. Interdisciplinary Dent., 2 (2), 84.

13. Walters, W.H. (2009). Google Scholar search performance: Comparative recall and precision. portal: Libraries and the Academy, 9 (1), 5-24.

14. Richter, R.R., \& Austin, T.M. (2012). Using MeSH (medical subject headings) to enhance PubMed search strategies for evidence-based practice in physical therapy. Phys. Ther., 92 (1), 124-132.

15. Listgarten, M.A., Lang, N.P., Schroeder, H.E., \& Schroeder, A. (1991). Periodontal tissues and their counterparts around endosseous implants. Clin. Oral Implants Res., 2 (1), 1-19.

16. Hermann, J.S., Buser, D., Schenk, R.K., Higginbottom, F.L., \& Cochran, D.L. (2000). Biologic width around titanium implants. A physiologically formed and stable dimension over time. Clin. Oral Implants Res., 11 (1), $1-11$.

17. Cochran, D.L., Hermann, J.S., Schenk, R.K., Higginbottom, F.L., \& Buser, D. (1997). Biologic width around titanium implants. A histometric analysis of the implanto gingival junction around unloaded and loaded nonsubmerged implants in the canine mandible. J. Periodontol., 68 (2), 186-197.

18. Makigusa, K. (2009). Histologic comparison of biologic width around teeth versus implant: The effect on bone preservation. J. Implant Reconstr. Dent., 1 (1), 2024.

19. Schmidt, J.C., Sahrmann, P., Weiger, R., Schmidlin, P.R., \& Walter, C. (2013). Biologic width dimensions-a systematic review. J. Clin. Periodontol., 40 (5), 493-504.

20. Romanos, G.E., Traini, T., Johansson, C.B., \& Piattelli, A. (2010). Biologic width and morphologic characteristics of soft tissues around immediately loaded implants: studies performed on human autopsy specimens. J. Periodontol., 81 (1), 70-78.

21. Atsuta, I., Ayukawa, Y., Kondo, R., Oshiro, W., Matsuura, Y., Furuhashi, A., ... \& Koyano, K. (2016). Soft tissue sealing around dental implants based on histological in- terpretation. J. Prosthodont. Res., 60 (1), 3-11.

22. Hermann, J.S., Cochran, D.L., Hermann, J.S., Buser, D., Schenk, R.K., \& Schoolfield, J.D. (2001). Biologic width around one and two piece titanium implants: A histometric evaluation of unloaded nonsubmerged and submerged implants in the canine mandible. Clin. Oral Implants Res., 12 (6), 559-571.

23. Selliseth, N.J., \& Selvig, K.A. (1995). Microvascular adaptation to transmucosal implants. A scanning electron microscopic study in the rat. Clin. Oral Implants Res., 6 (4), 205-212.

24. Moon, I.S., Berglundh, T., Abrahamsson, I., Linder, E., \& Lindhe, J. (1999). The barrier between the keratinized mucosa and the dental implant: an experimental study in the dog. J. Clin. Periodontol., 26 (10), 658-663.

25. Cochran, D.L., Obrecht, M., Weber, K., Dard, M., Bosshardt, D., Higginbottom, F. L., ... \& Jones, A.A. (2014). Biologic width adjacent to loaded implants with machined and rough collars in the dog. Int. J. Periodont. Restorative Dentistry, 34 (6), 773-779.

26. Blanco, J., Alves, C. C., Nuñez, V., Aracil, L., Muñoz, F., \& Ramos, I. (2010). Biological width following immediate implant placement in the dog: flap vs. flapless surgery. Clin. Oral Implants Res., 21 (6), 624-631.

27. Negri, B., Lopez Mari, M., Maté Sánchez de Val, J.E., Iezzi, G., Bravo González, L. A., \& Calvo Guirado, J.L. (2015). Biological width formation to immediate implants placed at different level in relation to the crestal bone: an experimental study in dogs. Clin. Oral Implants Res., 26 (7), 788-798.

28. Sculean, A., Gruber, R., \& Bosshardt, D. D. (2014). Soft tissue wound healing around teeth and dental implants. Journal of Clinical Periodontology, 41, S6-22.

29. Berglundh, T., Lindhe, J., Ericsson, I., Marinello, C. P., Liljenberg, B., \& Thornsen, P. (1991). The soft tissue barrier at implants and teeth. Clinical Oral Implants Research, 2 (2), 81-90.

30. Judgar, R., Giro, G., Zenobio, E., Coelho, P. G., Feres, M., Rodrigues, J. A., ... \& Shibli, J. A. (2014). Biological width around one-and two-piece implants retrieved from human jaws. BioMed Research International, 2014, 850120.

31. Spinato, S., Stacchi, C., Lombardi, T., Bernardello, F., Messina, M., \& Zaffe, D. (2019). Biological width establishment around dental implants is influenced by abutment height irrespective of vertical mucosal thickness: A cluster randomized controlled trial. Clinical Oral Implants Research, 30(7), 649-659.

32. Vervaeke, S., Dierens, M., Besseler, J., \& De Bruyn, H. (2014). The influence of initial soft tissue thickness on per implant bone remodeling. Clinical Implant Dentistry and Related Research, 16 (2), 238-247. 